\title{
Development of diagnostic tools and ensuring the financial and budgetary security of the region
}

\author{
Elena Karanina ${ }^{1, *}$, Mihail Kyzyurov ${ }^{1}$, and Svetlana Chuchkalova ${ }^{1}$ \\ ${ }^{1}$ Vyatka State University, Moskovskaya St., 36, 610000 Kirov, Russia
}

\begin{abstract}
The aim of the study is to analyze and improve the system of theoretical and economic tools for diagnosis and ensuring financial and budgetary security. The scientific approaches to the disclosure of the concept of the mechanism of ensuring economic security, the most important part of which is financial and budgetary security, are investigated. The above mechanism in these works is studied only within the framework of the national level (macro level), while due attention is not paid to the study of this concept at the regional level (mesoscale). The article formulates the concept of "a mechanism for ensuring the financial and budgetary security of the region", and also proposes a new diagnostic toolkit for indicators of financial and budgetary security at the regional level, which was tested on the example of the Kirov region.
\end{abstract}

\section{Introduction}

In order to explore the concept of a mechanism for ensuring the financial and budgetary security of a region, it is necessary to determine the origin and content of the definition of "mechanism". The term "mechanism" has Greek roots and comes from the word "mechane", which literally means "instrument", "machine".

In modern economic literature there are many scientific approaches to the content of this phenomenon, so the studied concept is actively used in works devoted to economic topics.

In Soviet times, the mechanism was understood as a specific system of elements guaranteeing the effective achievement of the socialist state goals and the most complete satisfaction of social collective and individual needs and interests. According to Soviet authors, these elements include, first of all, the legal organizational form of the organization and structure of management, and secondly, a set of methods and levers of influence, with the help of which the State effectively impacts on the economic system .

According to the Oxford Dictionary, a mechanism is defined, firstly, as a system of elements working together and ensuring the operation of a machine, and secondly, as a natural or established process by which something happens or is brought about.

In the economic dictionary, the term "mechanism" is defined as a system, a device that determines the order of any action.

\footnotetext{
* Corresponding author: kafinanc@yandex.ru
} 
With regard to the economic sphere in literature, many authors use such a concept as a household mechanism. In our opinion, the adjective "household", in this case, has a similar meaning with the word "economic", since the word "economy" from ancient Greek means "the art of household".

In general, a narrow and broad approach to the interpretation of concept of economic mechanism can be distinguished. Thus, according to the narrow approach, the economic mechanism is a set of tools with which the state and society regulate economic processes. Apologists broad approach adhere to the position, it is impossible to fully disclose the essence of the definition of "economic mechanism", not taking into account the effect of domestic laws regulating economic relations. Proponents of this approach believe that the term "economic mechanism" is identical in content to the concept of the economy.

The most important component of the economic mechanism, in our opinion, is the mechanism of ensuring economic security, through which a sustainable and stable state of the economy, prevention and elimination of emerging risks, threats and challenges to economic security is achieved. In turn, as a part of this mechanism, one can single out a mechanism for ensuring financial and budgetary security, aimed at maintaining the stability of the financial and budgetary sphere. Since the subject of this study is the analysis of fiscal security at the meso level (regional level of the constituent entities of the Russian Federation), here we will use the concept of a mechanism for ensuring fiscal security of the region. Prior to that time, there are no studies in the literature devoted to the concept of the mechanism of ensuring the financial and budgetary security of the region, however, there are studies devoted to the concept of the mechanism of ensuring economic security. We will try to adapt the existing approaches to the study of the mechanism of ensuring the financial and budgetary security of the region.

Based on the analysis of available scientific works, it can be stated that most researchers consider the mechanism of ensuring economic security as a combination of various tools, procedures, managerial decisions, regulatory legal acts, means, measures and methods used by the state to prevent the emergence and subsequent elimination of threats to economic security, maintain sustainable development and economic growth. In general, this approach can be called instrumental.

I. V. Chistnikova, M. V. Antonova, S. V. Yakimchuk, A. S. Glotova, E. A. Dynnikov believe that the economic security mechanism is a system of economic instruments and procedures applied and used by government bodies at both the federal and regional levels, allowing the state to effectively fulfill the functions of protecting the country's economic security [1].

E. V. Matveeva considers the mechanism of ensuring economic security as a complex system of components, including tools in the organizational and economic aspect, certain management decisions and audit forms, as well as the choice of measures to prevent, neutralize and eliminate threats identified by special services, thereby creating an internal environment that prevents their occurrence. All tools to ensure the economic security of the regions E. E. Matveeva is divided into several types:

1) Information and analytical measures, to which the researcher relates, firstly, monitoring the levels of socio-economic development of the constituent entities of the Russian Federation, and secondly, a system of indicators for assessing the economic development of the region.

2) Regulatory measures, according to E. E. Matveeva, include the adoption of laws, resolutions of executive and legislative authorities of the regions within their competence, as well as the elimination of crisis trends in the economy of the region.

3) Direct action measures, including programs for overcoming the crisis, development and implementation of programs for the socio-economic development of regions and 
raising extrabudgetary funds, improving the economic, social and budgetary effectiveness of managing a constituent entity of the Russian Federation, preventing and solving economic crimes throughout the region [2].

A. Ianioglo, T. Polajeva understand a mechanism for ensuring economic security as a set of public authorities, tools, methods and measures aimed at protecting against potential external and internal threats that can lead to economic losses [3].

Yu.G. Leschenko, S.E. Bolonina reckon that the mechanism for ensuring economic security is a system of organizational, economic and legal standards for identifying and preventing foreign economic threats [4].

Table 1 summarizes the considered approaches to the concept of the mechanism of economic security mechanism.

Table 1. Approaches to the concept of a mechanism for ensuring economic security.

\begin{tabular}{|l|l|}
\hline \multicolumn{1}{|c|}{ Author } & \multicolumn{1}{c|}{ Defining a mechanism for ensuring economic security } \\
\hline $\begin{array}{l}\text { I.V. Chistnikova, } \\
\text { M.V. Antonova, } \\
\begin{array}{l}\text { S.V. Yakimchuk, } \\
\text { A.S. Glotova, } \\
\text { E.A. Dynnikov }\end{array}\end{array}$ & $\begin{array}{l}\text { From the system of economic instruments and procedures applied and } \\
\text { used by state authorities at both the federal and regional levels allowing } \\
\text { economic security. }\end{array}$ \\
\hline E.V. Matveeva & $\begin{array}{l}\text { A comprehensive system of components, including tools in the } \\
\text { organizational and economic aspect, certain management decisions and } \\
\text { audit forms, as well as the choice of measures to prevent, neutralize and } \\
\text { eliminate threats identified by special services, creating an internal } \\
\text { environment that prevents their occurrence. }\end{array}$ \\
\hline $\begin{array}{l}\text { Yu.G. Leschenko, } \\
\text { S.E. Bolonina }\end{array}$ & $\begin{array}{l}\text { A system of organizational, economic and legal standards for identifying } \\
\text { and preventing foreign economic threats }\end{array}$ \\
\hline $\begin{array}{l}\text { A. Ianioglo, } \\
\text { T. Polajeva }\end{array}$ & $\begin{array}{l}\text { A set of public authorities, tools, methods and measures aimed at } \\
\text { protecting against potential external and internal threats that could lead to } \\
\text { economic losses. }\end{array}$ \\
\hline
\end{tabular}

\section{Materials and Methods}

In our opinion, the instrumental approach most fully reflects the essence of the concept under study, since the functioning of the mechanism for ensuring economic security is ensured by the activities of competent public authorities, which is expressed in the use of these tools, levers and methods. The static approach, in our opinion, on the contrary does not reflect the essential characteristics of the concept under consideration. Even a reference to the original meaning of the mechanism concept introduced into scientific circulation, as already noted by the Greeks, indicates the instrumental nature of this concept.

Thus, from the position of an instrumental approach on the basis of the foregoing, we will try to formulate the concept of a mechanism for ensuring the financial and budgetary security of the region, which, in our opinion, is a comprehensive system of tools, methods, regulatory legal acts, procedures, managerial decisions, measures and means used by state authorities of the region in order to prevent threats to the financial and budgetary security of the region, to neutralize them and eliminate their causes in occurrence, through which the stability is ensured, balance the functioning of the financial and budgetary sphere of the region, its development and improvement.

However, in our opinion, for the most comprehensive study of the definition of "mechanism for ensuring the financial and budgetary security of the region", it is also 
necessary to consider the content of the considering mechanism. On the basis of normative acts, as well as studies available in the scientific literature, we will try to highlight the main elements, structural components of the mechanism for ensuring the financial and budgetary security of the region.

In general, in our opinion, the structure of the mechanism for ensuring the financial and budgetary security of the region consists of three main components:

1) An organizational component that includes the following elements:

A) The purpose of the mechanism for ensuring the fiscal security of the region;

B) The principles of the organization of the mechanism for ensuring the financial and budgetary security of the region;

C) Regional economic interests;

D) Objects of financial and budgetary security of the region;

E) The subjects of financial and budgetary security in the region.

2) The regulatory component, which includes a system of regulatory legal acts and legal means aimed at ensuring the financial and budgetary security of the region.

3) Instrumental component, consisting of the following elements:

A) The directions of the policy of ensuring the financial and budgetary security of the region;

B) Methods for assessing the financial and budgetary security of the region

C) The process of ensuring the financial and budgetary security of the region.

Now we give a more detailed description of each of the elements of the studied mechanism. In our opinion, the purpose of the mechanism for ensuring financial and budgetary security in the region is related to the question of what role financial and budgetary security play in society. Finances are the circulatory system of the economy, and the well-being of individual citizens and the opportunities of development of the entire state and its regions ultimately depend on the normal functioning of the financial and budgetary sphere. The economy of the region cannot be developed properly without adequate financial support and fiscal regulation. Thus, the purpose of creating a mechanism for ensuring the financial and budgetary security of the regions is to ensure stability and sustainability, competitiveness, security, efficiency, independence of the financial and budgetary sphere, the progressive development and improvement, which in turn creates opportunities for improving the living standards of the region's inhabitants, its economic, industrial and innovative development.

The principles of the mechanism for ensuring the financial and budgetary security of the region include:

1) Observance and protection of the rights and freedoms of a man and a citizen;

2) Legality;

3) The consistency and complexity of the application by federal state governmental authorities, bodies of state power of a subject of the Russian Federation, other state bodies, bodies of local self-government authorities of political, organizational, socio-economic, informational, legal and other security measures;

4) The priority of preventive measures to ensure security;

5) Interaction of federal state governmental authorities, bodies of state power of a subject of the Russian Federation, other state bodies, bodies of local self-government authorities with public associations, international organizations and citizens in order to ensure security;

6) The principle of supremacy of state financial and budgetary interests without prejudice to related interests of external entities $[5 ; 6 ; 7]$.

7) The principle of balancing financial and budgetary interests means that in the process of activity of state authorities in the financial and budgetary sphere, it is necessary to choose non-confrontational methods of resolving contradictions [5]. 
8) The principle of differentiating the measurement of the value of socio-economic security reflects a change in the criteria for the functioning of economic systems and suggests that such configurations are expected in the future [5].

9) The principle of efficiency assumes that a safe state of the economic system is achieved at the lowest cost, provided that the maximum possible results are achieved [8].

10) The principle of openness of power implies the availability of information about the activities of public authorities for society, as well as the possibility of monitoring by civil society institutions over the activities of authorities.

11) The principle of responsibility and accountability implies a clear distribution of roles and competencies of the legislative and executive authorities, as well as the existence of a system of checks and balances, the authority to control in relation to each other.

12) The principle of subsidiarity implies that a public authority that occupies a higher level in the financial security apparatus intervenes in the activities of the lower level only if the latter does not fulfill its functions and responsibilities.

13) The principle of development and adaptation provides that the mechanism for ensuring financial security should be constantly improved, adapting to changes in the external environment.

14) The principle of the multiplicity of models provides the possibility of expressing different points of view on existing problems in the field of financial security, the ability to build various models to predict changes in the state of financial security, each of which has a right to exist.

15) The principle of consistency implies that financial security consists of hierarchically arranged in relation to each other subsystems, it is a multi-level structure.

16) The principle of bifurcation implies that the level financial security can vary significantly even with minor changes in its elements and the effects of factors that influence them.

17) The principle of coherence and subordination provides that the methods used by state authorities to ensure financial security should be consistent with each other and consistent with the satisfaction of the financial needs of the state.

18) The principle of international cooperation and integration implies compliance with international legal norms and standards, as well as the expansion of state participation in international security programs.

19) The principle of social responsibility implies that most members of the society feel the result of strengthening state of financial security.

20) The principle of behaviorism the state of financial security is also determined by the characteristics of the social organism, members of which make decisions aimed at ensuring financial security, namely: psychological, moral, mental, emotional factors; interpersonal communications; level of gender balance.

Regional economic interests include:

1) Stable reproduction and increase of natural-resource, economic, technicaltechnological, intellectual, innovative-investment, informational, social potential of the region;

2) Bringing the level and lifestyle of the population of the region in accordance with state and international standards.

3) The development of interregional ties;

4) The introduction of a new system of intergovernmental relations;

5) The development of technopolises, technology parks, research and production clusters [8].

Studying the issue of subjects of fiscal security, it should be noted that, in our opinion, in general, all subjects of fiscal security of the region can be divided into the following groups: 
1) Bodies of state and executive power of a subject of the Russian Federation, as well as law enforcement, fiscal, control and supervision bodies operating in the territory of this region;

2) Commercial organizations (large monopolist enterprises and corporations, foreign corporations, firms and small and medium-sized businesses, etc.);

3) Non-profit organizations;

4) Individuals;

5) The Central Bank of the Russian Federation which has its branches in the regions.

Under the object of financial and budgetary security, in our opinion, we should understand the totality of public relations arising in the fiscal, financial and credit sphere, as well as in the field of public administration and regulation of these relations at the level of subjects of Russia. In general, the structure of the object of fiscal security is as follows:

1) The financial sector, including fiscal and financial sectors, insurance, financial markets;

2) Government institutions.

The regulatory component of the financial and budgetary security of the regions includes 3 levels:

1) Federal level consists of the Constitution of the Russian Federation, federal constitutional laws, federal laws, decrees and orders of the President of Russia, decrees and orders of the Government of Russia, regulatory legal acts of the parliament, other regulatory legal acts regulating financial and budgetary security at the level of the Russian Federation, and at the level of constituent entities of the Russian Federation.

2) Regional level consists of constitutions (charters) of the constituent entities of the Russian Federation, laws of a constituent entity of the Russian Federation, decrees and orders of heads of regions, regulatory legal acts of representative bodies and executive bodies of constituent entities of Russia.

3) Local level consists of regulations of local authorities.

The mechanism for ensuring the financial and budgetary security of the region includes the following areas:

1. Budget policy;

2. Tax policy;

3. Monetary policy;

4. Investment policy;

5. Innovation policy;

6. Policies for the regional banking sector;

7. Industrial policy;

8. Anti-corruption policy;

9. Migration policy;

10. Demographic policy;

11. Policy in the field of development of small and medium enterprises;

12. Antimonopoly policy.

The process of ensuring the financial and budgetary security of the region consists of the following stages:

1. Strategic fiscal planning;

2. Formation of tasks to ensure the fiscal security of the region;

3. The definition of assessment methods;

4. Definition of indicators;

5. Assessment of the financial and budgetary security of the region;

6 . The application by the government of a complex of measures aimed at neutralizing the identified challenges, risks and threats to the financial and budgetary security of the region, as well as the reasons for their occurrence; 
7. Evaluation of the result;

The methods for assessing the financial and budgetary security of the region include:

1. Indicative;

2. Monitoring of base macroeconomic indicators and comparing them with threshold values;

3. Assessment of the region's economic growth rates based on the main macroeconomic and integrated indicators and their dynamics;

4. Expert method;

5. Assessment of quantitative damage caused;

6. Methods of applied mathematics;

7. Financial and budgetary control.

Thus, the mechanism for ensuring the financial and budgetary security of the region is a complex system that includes three components: organizational, regulatory and instrumental, each of which is closely interconnected with other components, has its own structure and is a necessary component that ensures functioning the whole mechanism.

\section{Results}

Based on generally accepted requirements and the developed system of indicators of economic security in general, it seems possible to identify 16 indicators of financial and budgetary security. It is advisable to divide the whole range of indicators into several areas:

1. Socio-economic sphere:

- The cost of living (RUB) indicates a sufficient amount of cash to ensure the normal functioning of the human body and maintain its health. For a safe condition, this indicator should be no less than that established by the Government of the Russian Federation.

- The share of the population with cash incomes below the subsistence level (\%) characterizes the number of people who are unable to provide themselves with an optimal standard of living in accordance with the established subsistence level. The excess of this indicator over the threshold value indicates the inefficiency of the monetary policy. Threshold value $=7 \%$.

- Overdue salary arrears to employees (thousand rubles) - actually accrued salary amounts, but not paid on time. This indicator indicates the presence of workers who are actually deprived of livelihoods, which may occur as a result of the financial problems of the employer. With sp. developed state and socially responsible employers, this indicator should be equal to zero.

- The real disposable cash income of the population (\% of the previous year) is the income of the population net of mandatory payments (including taxes), recalculated for inflation. This indicator allows you to most objectively characterize the standard of living of the population. The threshold value is not less than the average income in Russia, namely $98.08 \%$.

- The ratio of funds (times) shows the degree of social stratification and is defined as the ratio between the average levels of cash income of $10 \%$ of the population with the highest incomes and $10 \%$ of the population with the lowest incomes. Exceeding the threshold value (8 times) for this indicator indicates growing social inequality.

- The inflation rate (\%) shows an increase in the general price level with a decrease in the purchasing power of money. The values of the indicator above the set inflation target indicate the inefficiency of the implemented anti-inflation policy. The inflation rate and target are regularly published on the official website of the Central Bank of Russia.

- Economic crime (including the shadow economy) (units), the existence of which indicates a worsening of the general economic conditions for enterprises and aggravation of social inequality. This indicator also indicates the insolvency of the current monetary 
policy, which contributes, among other things, to the prosperity of the shadow economy. Economic crime is almost impossible to eradicate, but, nevertheless, the zero value of this indicator is considered ideal.

2. Financial sphere:

- Investments in fixed assets (\% of GRP). This indicator is necessary to monitor the threat of underfunding of the needs of sustainable development of enterprises in the region. A constant increase in this indicator indicates the development and expansion of production. If the indicator value is less than the threshold value $(25 \%)$, then we can talk about obsolescence of equipment and the entire material and technical base.

- The proportion of unprofitable organizations (\%) shows the inability of a number of organizations to carry out their activities even with normal (zero) profit in order to stay in the industry. Reducing the number of efficient and profitable organizations can lead to undermining of market relations and worsening the financial condition of the region and the country. The actual value of the indicator should not exceed the national average (threshold value $=21.4 \%$ )

- The ratio of the number of newly created legal entities to officially liquidated (times). Changes in this indicator indicate both a decline and an increase in the total number of operating organizations in the region. The values of this indicator should be more than one.

3. Fiscal sphere:

- The deficit of the consolidated regional budget (\% of GRP) shows how much the expenses of the consolidated budget exceed its revenues. Of course, the deficit budget is quite acceptable, but its size should not be more than the threshold value (3\%).

- Government debt (\% of GRP) represents the outstanding amount of current liabilities that must be paid together with interest in the future. In our time, the existence of a public debt is not considered a catastrophic phenomenon, but at the same time, its value should not exceed $25 \%$.

- Debt on taxes and fees (million rubles), which is one of the significant destabilizing factors. The presence of this indicator should be one of the main signals of the rapid deterioration of monetary security. The threshold value in this case is not set, since under favorable conditions such an indicator should be equal to zero.

4. Credit sphere:

- The share of overdue debts on loans of legal entities and individual entrepreneurs in the total volume of loans issued (\%) shows the level of loans to legal entities and individual entrepreneurs, as well as indicates their increased financial dependence. The established threshold value (not more than $10 \%$ ) is due to the existence of a temporary factor in the activities of any legal entity.

- The share of overdue debts on loans to individuals in the total volume of loans issued (\%) shows the level of loans to individuals and their inability to repay existing debts. The existence of high values of this indicator (more than 10\%) can be both a cause and a consequence of growing problems in the economy and society.

- The number of regional credit organizations and branches of other credit organizations in the region (units) indicates the degree of saturation of the territory with credit organizations. Threshold value $=8$ units.

Despite such a division of indicators into spheres, it is important to consider them in a complex in order to build a real picture of the results of monetary policy.

Based on the selected indicators, it is necessary to determine the actual values, and then compare them with threshold values. Such a comparison allows us to identify factors that can cause the greatest damage, to trace their dynamics and values in the short term.

Then the final value of the indicators is calculated: in this case, the ideal state is when all the indicators correspond to threshold values. Knowing the final assessment of financial 
and budgetary security, you can track changes in its level over time and rank the areas according to their level of security.

It is proposed to compare the threshold values with the actual ones as follows. The ideal values for a particular indicator are assigned a zero value, then the correspondence of the actual data to the threshold is determined: if the indicator is in a safe zone, then it is equal to zero; if not, the difference in non-compliance is determined. Exceeding or not reaching the threshold value is summarized, and a comprehensive assessment of the level of security is formed.

In addition, it should be noted that some indicators (tax and debt arrears, economic crime, wage arrears to employees) will have the greatest weight in the final assessment, since the safe state of these indicators should be zero.

In order to identify the impact of fiscal security on overall economic security, it is necessary to compare the relevant indicators. This will allow us to see how changes in the sphere of state regulation in each case can improve or reduce the level of economic security.

The proposed methodology helps to eliminate gaps in the methodology for assessing economic security and expands the scope of scientific ideas about the diagnosis of its various elements. The practical application of this technique allows one to obtain a reliable assessment of economic security from so on. financial regulation.

To assess the performance of the developed system, it is necessary to consider it with so on. specific object, which is the Kirov region.

The calculation of indicators of economic security in the field of financial regulation in relation to the Kirov region was carried out for the period 2013-2018, and the values of these indicators were predicted for 2019-2021.

In the search for the source data for the calculation of indicators, statistical information was used from official documents of various structures (Rosstat, Kirovstat, EMISS, Ministry of Finance of the Kirov region, Central Bank of the Russian Federation). The predictive assessment was carried out by averaging the data obtained using the Microsoft Office Excel program, namely, by means of the Predict function and plotting a trend line.

As a result of the calculation, it was revealed that the Kirov region is not in a safe zone in any of the identified areas. Characterizing the obtained values of indicators by areas, it is important to note the following:

As of 2018, out of 7 indicators in the socio-economic sphere, only 2 indicators are in the safe zone. Moreover, one cannot even single out an indicator that did not violate the threshold value for the entire analyzed period. The characteristics of indicators in this area are presented in Figure 1.

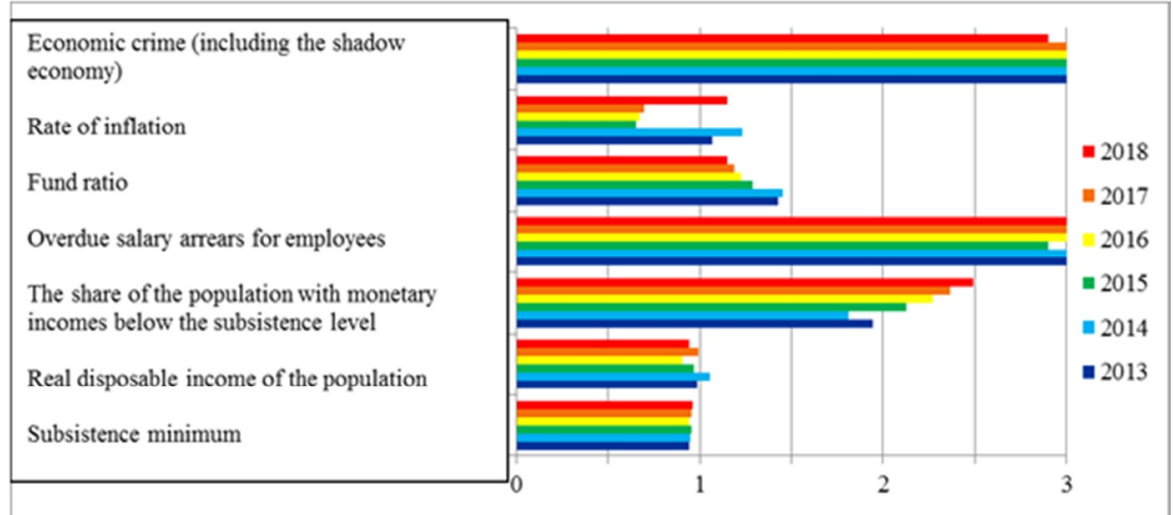

Fig. 1. Dynamics of the indices of indicators of financial and budgetary security, socio-economic sphere (threshold value $=1$ ). 
2. In the financial sector as of 2018 , out of 3 indicators, only 1 indicator is in the safe zone. Despite this, over the entire analyzed period, the values of the identified indicators tend to improve and exit the crisis zone. The graphically established situation is shown in Figure 2.

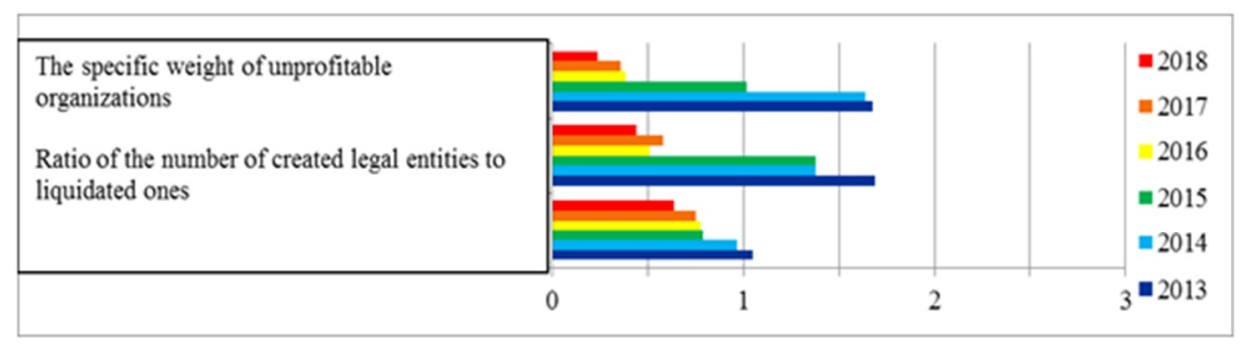

Fig. 2. Dynamics of the indices of indicators of financial and budgetary security, the financial sector (threshold value $=1)$.

3. As of 2018, out of 3 indicators in the fiscal sphere, in the safe zone there is only 1 indicator characterizing tax and debt arrears. This is primarily due to the fact that the values of the indicated indicator should be equal to zero at the best outcome. The remaining 2 indicators for the period under review were in a safe zone, while the indicator of budget deficit was most distant from the threshold value in the direction of improvement. The characteristics of indicators in this area are presented in Figure 3.

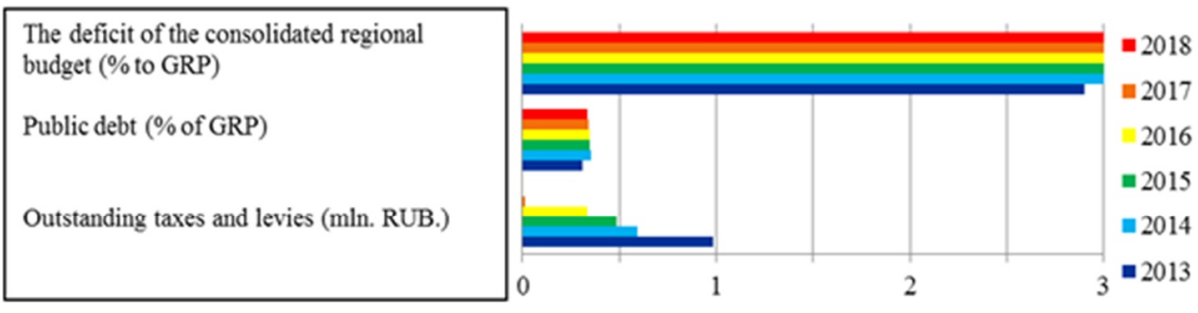

Fig. 3. Dynamics of the indices of indicators of financial and budgetary security, the fiscal sphere (threshold value $=1$ ).

4. In the credit sector, 3 indicators have been identified, each of which, as of 2018 , is in a safe zone or equal to a threshold value. out of 3 indicators, only 2 indicators are in the safe zone. Moreover, over the entire analyzed period, the values of the indicators have jump-like dynamics, exceeding or not reaching the threshold value. The graphically established situation is shown in Figure 4.

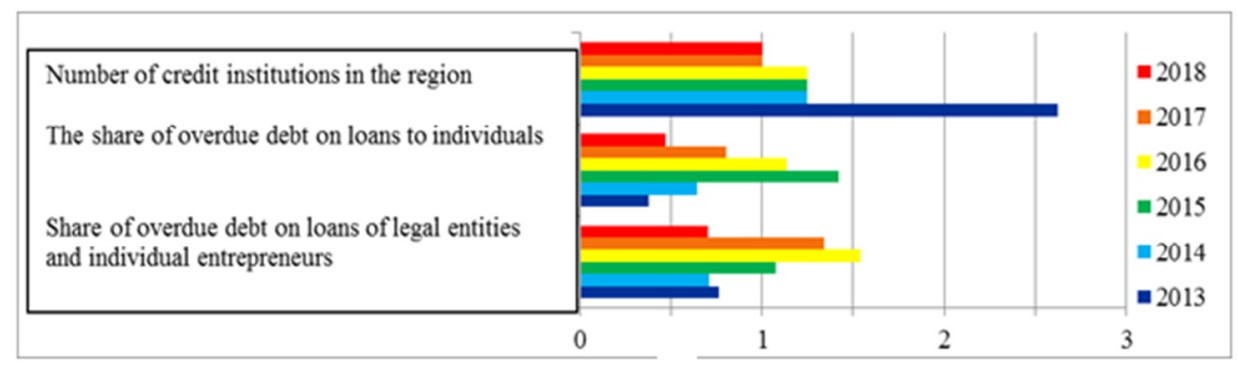

Fig. 4. Dynamics of indices of indicators of financial and budgetary security, credit sector (threshold value $=1)$. 
The maximum distant value of the indicator compared to the threshold can be noted in 3 indicators (tax and debt arrears, salaries, economic crime), because in case of violation of the planned amount of cash inflows or intensification of economic crime, a whole financing chain may be violated, which will lead to chain reaction and will be reflected in several areas at once. The threshold value of these indicators is zero, so they are all in the crisis zone.

Without resorting to dividing these indicators into areas, we can say that out of 16 security indicators as of 2018, the Kirov region is in a safe zone by 6 indicators (taking into account an indicator equal to the threshold value), and in dynamics for the whole analyzed period - only for 2 indicators (taking into account an indicator equal to the threshold value).

In order to give a general assessment of fiscal security, it is necessary to analyze the actual data and threshold values, which are the goal and ideal condition. For 2013-2018 economic security of the Kirov region in terms of monetary regulation had a spasmodic trend. At the same time, the most crisis state was noted in 2018 , and relatively safe - in 2015. Based on Figure 5, we can say that the overall level of monetary security in the region is several times worse than the ideal value, which ensures safe functioning and sustainable development.

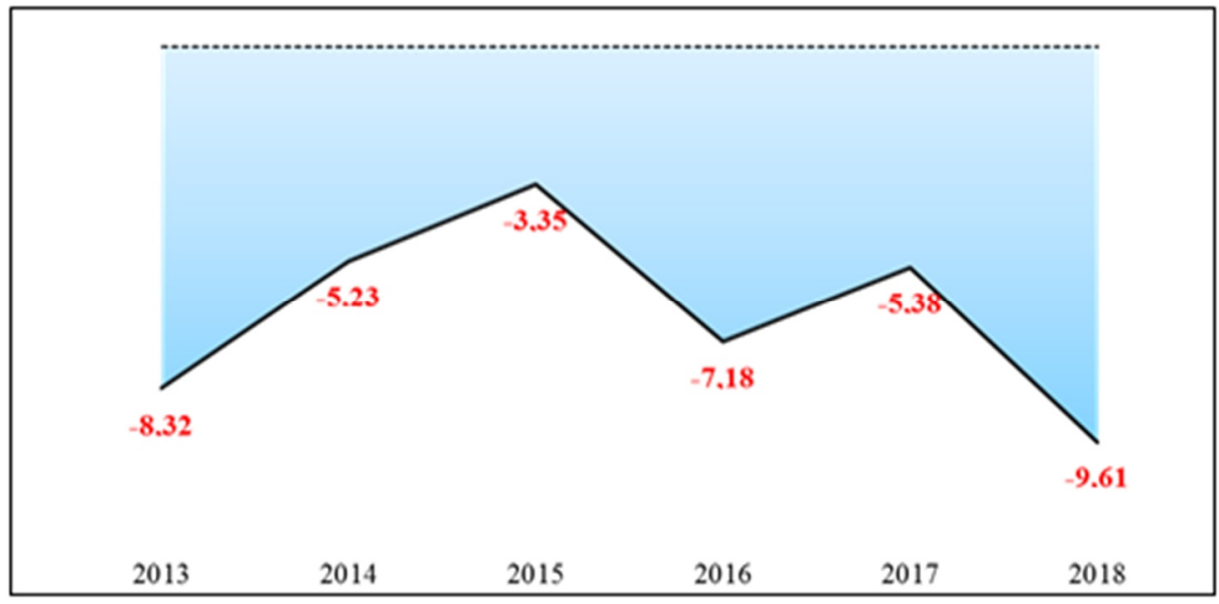

Fig. 5. The final assessment of financial and budgetary security of the Kirov region (threshold value $=$ $0)$.

\section{Discussion}

Analyzing the results, we can say that the financial and budgetary security of the Kirov region is in a crisis state, which poses a serious threat to its economic security and the national security of Russia.

Describing the data obtained, special attention should be paid to the following threats that pose the greatest danger to the Kirov region:

- the increase in the discrepancy between the subsistence level and the average value in Russia;

- an increase in the share of the population with cash incomes below the subsistence level;

- the growth of arrears on salaries to employees;

- reduction in investment;

- increase in the number of liquidated legal entities;

- increase in taxes and duties. 
Among the likely consequences of an exacerbation of such threats may include:

- increased social tension, the antagonization of society, its stratification of property, the growth of socially disadvantaged categories of citizens;

- weakening of the market mechanism, reducing the number of small and medium-sized enterprises;

- violation of the budget mechanism and government structure (reduction of tax revenues leads to the inability to finance regional interests);

- aggravation of the position of the Kirov region as a recipient region, activation of potential threats, a general drop in the level of economic security of the region.

The existence of identified threats to the security of the Kirov region, as in other regions of Russia, under a negative set of circumstances, can lead to the growth of discontent among citizens, which, ultimately, can lead to civil war, the redivision of our territory by neighboring regions or states, and the destruction of Russian sovereignty .

Obviously, ignoring the security problems of the Kirov region is a key threat to its economic security and integrity. Subsequent changes regarding this issue should be aimed, first of all, at improving the quality of life of the population, strengthening the competitiveness and financial stability of the region's enterprises, and at general socioeconomic development.

In addition, the following risks remain for the Kirov region, which differ slightly from the critical values:

- further reduction of incomes of the population;

- strengthening the financial stratification of society;

- the rapid increase in the general price level, their instability;

- impressive amounts of economic crime, including the shadow economy;

- increase in the scale of unprofitable organizations;

- reduction in the number of newly created legal entities;

- aggravation of loans of legal entities and individuals.

\section{Conclusion}

The effectiveness and feasibility of the developed system of indicators of financial and budgetary security was proved by calculating these indicators of the region of the Russian Federation - the Kirov region. As a result of comparing the actual data of the selected indicators and their threshold values, it was revealed that the Kirov region is in a crisis state: as of 2018, out of 16 indicators, only 6 indicators correspond to threshold values. Such an assessment of the level of security indicates the need for immediate adoption of reasonable and effective measures that can minimize existing threats and slow down the rate of deterioration of the regional economy.

Consistent and effective measures to strengthen fiscal security within the framework of the mechanism for ensuring it will also strengthen the economic security of the region. This effect is possible due to the strong relationship between financial and economic security.

Using a set of measures in the field of financial and budgetary regulation, it is possible not only to ensure sustainable progressive development of the region, the competitiveness of its business entities and the necessary level of well-being, but also to strengthen the economic security of the region, which will also contribute to national security.

\section{References}

1. I.V. Chistnikova, M.V. Antonova, S.V. Yakimchuk, A.S. Glotova, Y.A. Dynnikov, Regional Science Inquiry IX(1), 103 (2017) 
2. E.E. Matveeva, Vestnik of Moscow University of the Ministry of Internal Affairs of Russia 6, 286 (2018) doi 10.24411/2073-0454-2018-10056

3. A. Ianioglo, T. Polajeva, Int. J. Learning and Change 9(1), 60 (2017) doi: 10.1504/IJLC.2017.084223

4. J.G. Leshchenko, S.E. Bolonina, Journal of international economic affairs 9(1), 12 (2019) doi: 10.18334/eo.9.1.39923

5. D. Shvaiba, Bulletin of science and practice V(2), 222-227 (2019) https://doi.org/10.33619/2414-2948/39/29

6. D. Shvaiba, Bulletin of Science and Practice 4(6), 248-254 (2018) doi: 10.5281/zenodo. 1289862

7. D. Shvaiba, Bulletin of Science and Practice 4(6), 233-239 (2018) doi:10.5281/zenodo. 1289852

8. D. Shvaiba, Bulletin of Science and Practice 5(2), 228-234 (2019) DOI: $10.33619 / 2414-2948 / 46$ 